\title{
Evaluasi Fungsi Ekologis Taman Kota dalam Upaya Peningkatan Kualitas Ruang Perkotaan
}

\author{
Alma Ukhtiani Nurhasan*, Verry Damayanti \\ Prodi Teknik Perencanaan Wilayah \& Kota, Fakultas Teknik, \\ Universitas Islam Bandung, Indonesia. \\ *almaukhtianin231@gmail.com, unisbavd@gmail.com
}

\begin{abstract}
Increased development in Bandung, combined with high rate of population growth, causes a decrease in environmental quality. Because a primary function is as an ecological function, namely as a means to reduce pollutants and prevent changes in environmental quality, the existence of city parks can reduce the potential for environmental degradation that occurs. The purpose of this study was to evaluate the quality of city parks in the Bandung Wetan District based on ecological functions in order to build a city park arrangement capable of raising the quality of urban space in a sustainable way. The ecological functions analyzed are the noise barrier function, the temperature modification function, the air humidity control function, the windbreak function, the water management function and soil buffer function and the function as animal habitat. Analysis of the Suitability of Ecological Functions Based on Vegetation Using the Key Performances Index (KPI) Analysis Method, Environmental Condition Assessment, and Functional Analysis of City Parks as Animal Habitats are the analytical methods used. According to the results, the vegetation condition in Taman Lansia of the five (5) ecological functions is in the good category, while the measurement of environmental conditions in Taman Lansia of the five (5) functions is in the ideal category. According to the results of an analysis of the function of city parks as animal habitats, the following factors influence the diversity of animal species in urban parks: the size of the park, the diversity of vegetation types, and the frequency of visitor activities.
\end{abstract}

Keywords: Urban Parks, Ecological Functions, Environmental Quality.

\begin{abstract}
Abstrak. Meningkatnya pembangunan disertai dengan tingginya laju pertumbuhan penduduk di Kota Bandung menyebabkan penurunan kualitas lingkungan. Adanya Taman Kota dapat mengurangi potensi penurunan kualitas lingkungan yang terjadi, karena fungsi utamanya sebagai fungsi ekologis yaitu sebagai media untuk mereduksi polutan dan mencegah terjadinya perubahan kualitas lingkungan. Tujuan dari penelitian ini adalah untuk mengevaluasi kualitas dari Taman Lansia Kota Bandung berdasarkan fungsi ekologis agar terwujudnya penataan taman kota yang mampu meningkatkan kualitas ruang perkotaan secara berkelanjutan. Ada pun fungsi ekologis yang di analisis adalah fungsi penahan kebisingan, fungsi modifikasi suhu, fungsi pengontrol kelembapan udara, fungsi penahan angin, fungsi pengatur tata air dan peyangga tanah dan fungsi sebagai habitat satwa. Metode analisis yang digunakan yaitu Analisis Kesesuaian Fungsi Ekologis Berdasarkan Vegetasi menggunakan metode analisis Key Performances Index (KPI), Penilaian Kondisi Lingkungan. dan Analisis deskriptif Fungsi Taman Kota sebagai habitat satwa. Berdasarkan hasil analisis, Kondisi Vegetasi pada Taman Lansia dari ke lima (5) fungsi ekologis, tiga (3) yang termasuk ke dalam kategori baik, sementara untuk Pengukuran kondisi lingkungan pada Taman Lansia dari ke lima (5) fungsi dua (2) fungsi yang memenuhi kondisi ideal. Berdasarkan hasil analisis fungsi taman kota sebagai habitat satwa menunjukan bahwa faktor yang mempengaruhi keanekaragaman jenis satwa pada taman kota diantaranya yaitu : luas taman, keanekaragaman jenis vegetasi dan intensitas aktifitas pengunjung.
\end{abstract}

Kata Kunci: Taman Kota, Fungsi Ekologis, Kualitas Lingkungan. 


\section{A. Pendahuluan}

Salah satu cara untuk tetap menjaga kelestarian lingkungan adalah dengan cara membangun Ruang Terbuka Hijau (RTH). Ruang Terbuka Hijau (RTH) merupakan suatu tempat yang dapat dikunjungi secara bebas atau bersifat umum dan terbuka serta di dalamnya difungsikan sebagai tempat bertumbuhnya tanaman yang tumbuh secara alami mau pun sengaja ditanami. Ruang terbuka hijau memiliki bermacam-macam jenis salah satunya adalah taman kota. Ruang Terbuka Hijau (RTH) memiliki fungsi untuk mengatur peranan dari kondisi lingkungan di suatu wilayah terutama pada wilayah perkotaan, karena di wilayah perkotaan banyak berbagai macam kegiatan yang pada akhirnya kegiatan tersebut menimbulkan masalah bagi lingkungan. Ruang terbuka hijau (RTH) ini memiliki fungsi utama salah satunya yaitu sebagai fungsi ekologi. Fungsi ekologis diantaranya yaitu ruang terbuka hijau berfungsi sebagai peredam kebisingan, pengendali iklim dan juga sebagai pelindung habitat satwa artinya Ruang Terbuka Hijau (RTH) diharapkan dapat menjaga keberlanjutan suatu wilayah/kota dengan cara menekan potensi pencemaran yang dapat merusak lingkungan sekaligus sebagai wadah untuk konservasi lingkungan.

Adanya peningkatan aktifitas perkotaan di Kecamatan Wetan, akibat meningkatnya aktifitas perkotaan menimbulkan dampak negatif terutama terhadap kualitas lingkungan. Dampak negatif tersebut diantaranya dapat berupa pencemaran udara, pencemaran suara, pencemaran tanah, dan lain-lain. Kecamatan Bandung Wetan mulai mengalami tanda-tanda penurunan kualitas lingkungan yang ditandai dengan perubahan cuaca, hal tersebut ditandai dengan meningkatnya suhu akibat aktifitas perkotaan. Menurut data dari BMKG Kota Bandung, peningkatan suhu terjadi dari tahun 2017-2019. Rata-rata peningkatan suhu setiap tahunnya sebesar $1,07^{\circ} \mathrm{C}$ dan jika dibandingkan dengan rata-rata suhu selama 20 tahun terakhir menunjukan suhu yang lebih hangat. Karena kondisi tersebut, adanya Ruang Terbuka Hijau (RTH) sangat bermanfaat untuk dapat mengurangi potensi tanda-tanda perubahan kualitas lingkungan. Berdasarkan Data Dinas Perumahan dan Kawasan Permukiman, Pertanahan dan Pertamanan, Kecamatan Bandung Wetan merupakan kecamatan dengan jumlah terbanyak yaitu sebanyak 60 unit dengan luas total seluas 597.616,39 $\mathrm{m}^{2}$. Dengan adanya keberadaan Taman Kota, seharusnya permasalahan tersebut bisa diatasi, karena hal yang terpenting dan harus terpenuhi dalam pembangunan taman kota adalah fungsi taman itu sendiri sebagai Ruang Terbuka Hijau (RTH) yaitu sebagai fungsi ekologis. Fungsi ekologis merupakan sebuah proses fisik, kimia dan biologi yang membantu menjaga keseimbangan ekosistem dan juga menyediakan sistem penyangga kehidupan seperti air, tanah dan udara secara baik dan berkelanjutan.

Adanya taman kota sebagai ruang terbuka hijau (RTH) merupakan sebagai ruang buatan yang berfungsi sebagai penunjang fungsi ekologi, dengan adanya taman kota sebagai ruang buatan untuk menunjang fungsi ekologi dapat meminimalisir perubahan terhadap kualitas lingkungan. Oleh karena, itu perlu adanya kajian lebih lanjut mengenai evaluasi fungsi ekologis pada Taman Kota di Kecamatan Bandung Wetan dengan studi kasus Taman Lansia agar fungsi dari Taman Kota sebagai Ruang Terbuka Hijau (RTH) dapat dimanfaatkan dan terasa fungsinya secara optimal mau pun berkelanjutan. Evaluasi terhadap taman kota sebagai Ruang Terbuka Hijau (RTH) yang telah dibangun dibutuhkan untuk mengetahui sejauh mana kinerja taman kota dalam pemenuhan fungsi yang sebagaimana diharapkan.

\section{B. Metodologi Penelitian}

Pada penelitian ini menggunakan metode penelitian mixed method dengan pendekatan empirik. Metode penelitian mixed method atau metode penelitian campuran adalah metode dalam penelitian yang mengkombinasikan atau menggabungkan antara metode penelitian kualitatif dan kuantitatif. Sementara pendekatan empiris bersifat nyata, apa adanya, dan sesuai dengan fakta yang ada di lapangan. Maka pada penelitian ini dalam memperoleh informasi peneliti melalukan studi lapangan. Dalam penelitian ini, data primer dan data sekunder digunakan sebagai metode pengumpulan data. Ada pun data yang diperlukan diantaranya sebagai berikut : 
1. Suhu dan Kelembapan udara

2. Kecepatan Angin

3. Tingkat Kebisingan

4. Laju Infiltrasi

5. Jenis Satwa yang ada di Taman Lansia

Analisis yang digunakan dalam penelitian ini diantaranya adalah Analisis Kesesuaian Fungsi Ekologis Berdasarkan Vegetasi dengan menggunakan Key Performances Index (KPI) dengan cara memberikan bobot nilai terdiri atas 4 (empat) kategori yaitu buruk, sedang, baik dan sangat baik, dimana penilaian tertinggi (sangat baik) untuk penilaiannya diberi poin 4 dan untuk penilaian terendah (buruk) penilaiannya diberi poin 1. Pemberian poin tersebut berdasarkan kesesuaian ciri-ciri fisik dari masing-masing variabel yang akan diteliti. Kemudian diolah menggunakan rumus berikut :

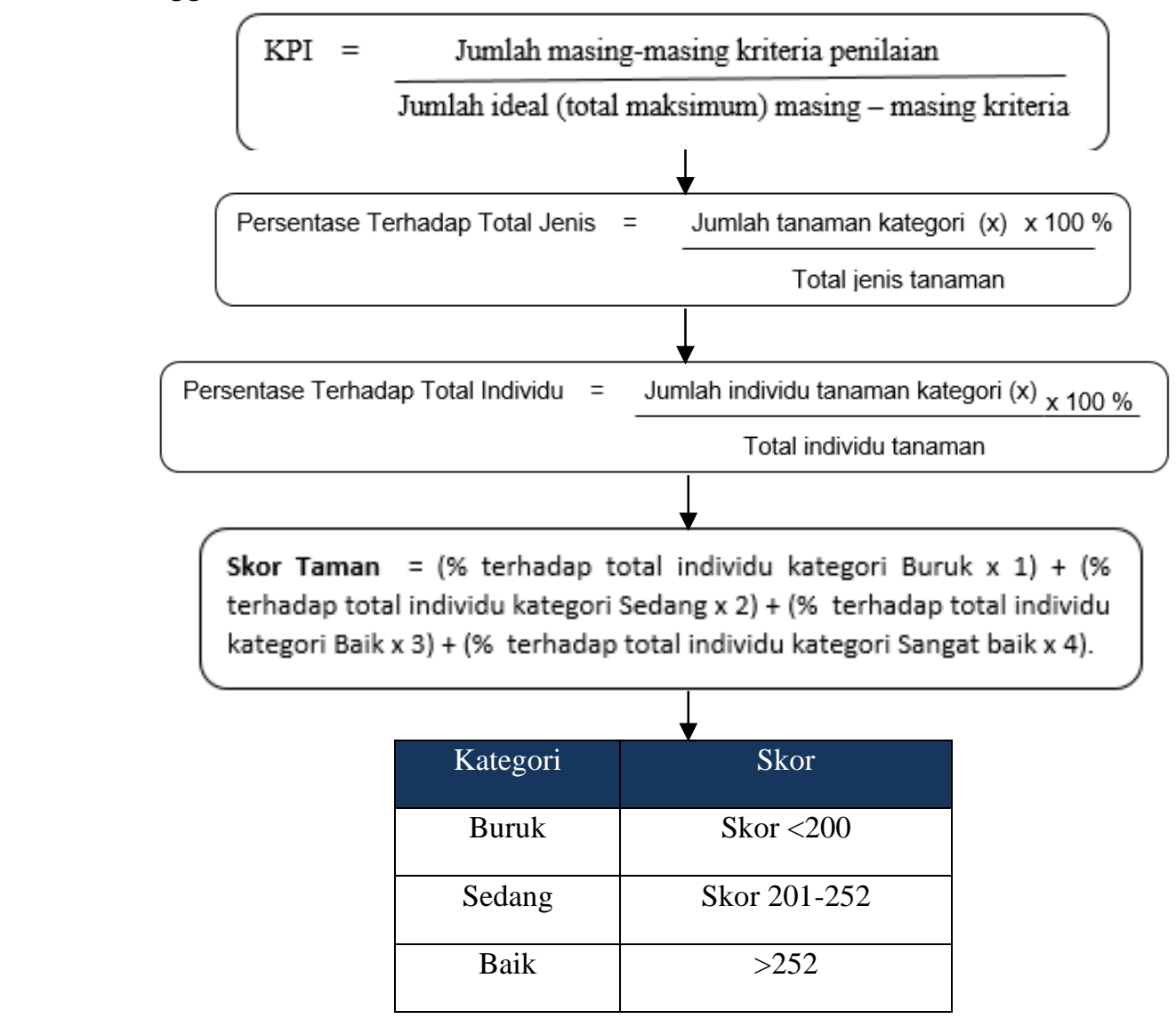

Sumber : Hasil Pengolahan, 2021

Kemudian untuk Penilaian Kondisi Lingkungan dengan cara melakukan pengukuran, kemudian data hasil pengukuran pengukuran disesuaikan dengan indikator penilaianyang sudah ditentukan pada Tabel 1. Rekapitulasi Hasil Pengukuran Kondisi Lingkungan. sementara untuk Analisis Fungsi Habitat Satwa dilakukan dengan cara mendeskripsikan data sebaran satwa di Taman Lansia. 
Tabel 1. Rekapitulasi Hasil Pengukuran Kondisi Lingkungan

\begin{tabular}{|c|c|c|c|c|}
\hline No. & Fungsi & Indikator & Terpenuhi & $\begin{array}{c}\text { Tidak } \\
\text { Terpenuhi }\end{array}$ \\
\hline 1. & Peredam Kebisingan & $\begin{array}{l}\text { Dapat mereduksi kebisingan hingga } \\
10 \mathrm{~dB}\end{array}$ & & \\
\hline 2. & Modifikasi Suhu & Dapat mengurangi suhu hingga $3,5^{\circ} \mathrm{C}$ & & \\
\hline 3. & $\begin{array}{l}\text { Pengontrol Kelembapan } \\
\text { Udara }\end{array}$ & $\begin{array}{l}\text { Kelembapan relatif dalam taman } \\
\text { antara } 40-75 \%\end{array}$ & & \\
\hline 4. & Penahan Angin & $\begin{array}{l}\text { Dapat menahan kecepatan angin } \\
\text { sebesar } 40-50 \% \text { dari kecepatan angin } \\
\text { di luar tapak }\end{array}$ & & \\
\hline 5. & $\begin{array}{l}\text { Penyangga Tanah dan } \\
\text { Pengatur Tata Air }\end{array}$ & Waktu kecepatan infitrasi yang cepat & & \\
\hline
\end{tabular}

Sumber : Carpenter et al. (1975).Grey dan Daneke (1978), Laurie (1986)

\section{Hasil Penelitian dan Pembahasan}

\section{Analisis Fungsi Ekologis Taman Lansia Berdasarkan Vegetasi}

Dalam analisis ini terdapat 5 fungsi yang dinilai, dari masing-masing variabel tersebut memiliki indikator penilaian yang berbeda. Ada pun fungsi-fungsi tersebut diantaranya yaitu fungsi peredam kebisingan, fungsi modifikasi suhu, fungsi pengontrol kelembapan udara, fungsi penahan angin, dan fungsi penyangga tanah dan pengatur tata air. Analisis dilakukan dengan cara memberi nilai terhadap vegetasi untuk tiap-tiap fungsi dengan indikator penilaian yang berbeda-beda menggunakan metode analisis Key Performances Index (KPI). Dari hasil analisis berupa perkiraan kualitas dari masing-masing fungsi vegetasi.

Tabel 1. Skor Total Penilaian Fungsi Ekologis Peredam Kebisingan Berdasarkan Vegetasi

\begin{tabular}{|c|c|c|c|c|}
\hline Kategori & Jumlah Jenis & Jumlah Individu & \% Terhadap total Jenis & \% Terhadap total Individu \\
\hline SB & - & - & - & - \\
\hline BK & 3 & 10 & 23 & 4 \\
\hline S & 10 & 241 & 77 & 96 \\
\hline B & - & - & - & 204 \\
\hline \multicolumn{7}{r}{ Skor total fungsi } \\
\hline
\end{tabular}

Sumber : Hasil Observasi, 2021

Skor Taman $=(\%$ terhadap total individu kategori Buruk $\mathrm{x} 1)+(\%$ terhadap total individu kategori Sedang x 2) $+(\%$ terhadap total individu kategori Baik x 3$)+(\%$ terhadap total individu kategori Sangat baik x 4).

Keterangan Kategori Fungsi :

1. Buruk : $<200$

2. Sedang : 201-252

3. Baik : $>252$

Tabel 2. Skor Total Penilaian Fungsi Ekologis Modifikasi Suhu Berdasarkan Vegetasi

\begin{tabular}{|c|c|c|c|c|}
\hline Kategori & Jumlah Jenis & Jumlah Individu & \% Terhadap Total Jenis & \% Terhadap Total Individu \\
\hline SB & 3 & 131 & 23 & 52 \\
\hline BK & 10 & 120 & 77 & 48 \\
\hline S & - & - & - & - \\
\hline B & - & - & - & 352 \\
\hline
\end{tabular}

Sumber : Hasil Observasi, 2021 
Skor Taman $=(\%$ terhadap total individu kategori Buruk x 1$)+(\%$ terhadap total individu kategori Sedang x 2) + (\% terhadap total individu kategori Baik x 3) + (\% terhadap total individu kategori Sangat baik x 4).

Keterangan Kategori Fungsi :

1. Buruk $:<200$

2. Sedang : 201-252

3. Baik : $>252$

Tabel 3. Skor Total Penilaian Fungsi Ekologis Pengontrol Kelembapan Udara berdasarkan Vegetasi

\begin{tabular}{|c|c|c|c|c|}
\hline Kategori & Jumlah Jenis & Jumlah Individu & \% Terhadap Total Jenis & \% Terhadap Total Individu \\
\hline SB & - & - & - & - \\
\hline BK & 2 & 49 & 15 & 16 \\
\hline S & 11 & 211 & 85 & 84 \\
\hline B & - & - & - & - \\
\hline \multicolumn{5}{r}{ Skor total fungsi } \\
\hline
\end{tabular}

Sumber : Hasil Observasi, 2021

Skor Taman $=(\%$ terhadap total individu kategori Buruk x 1$)+(\%$ terhadap total individu kategori Sedang x 2) + (\% terhadap total individu kategori Baik x 3) + (\% terhadap total individu kategori Sangat baik x 4).

Keterangan Kategori Fungsi :

1. Buruk $:<200$

2. Sedang : 201-252

3. Baik : $>252$

Tabel 4. Skor Total Fungsi Ekologis Penahan Angin Berdasarkan Vegetasi

\begin{tabular}{|c|c|c|c|c|}
\hline Kategori & Jumlah Jenis & Jumlah Individu & \% Terhadap Total Jenis & \% Terhadap Total Individu \\
\hline SB & 1 & 2 & 8 & 1 \\
\hline BK & 10 & 228 & 77 & 91 \\
\hline S & 3 & 2 & 15 & 8 \\
\hline B & - & - & - & - \\
\hline \multicolumn{5}{|c|}{ Skor total fungsi } \\
\hline
\end{tabular}

Sumber : Hasil Observasi, 2021

Skor Taman $=(\%$ terhadap total individu kategori Buruk x 1$)+(\%$ terhadap total individu kategori Sedang x 2) $+(\%$ terhadap total individu kategori Baik x 3) $+(\%$ terhadap total individu kategori Sangat baik x 4).

Keterangan Kategori Fungsi :

1. Buruk $:<200$

2. Sedang : 201-300

3. Baik : $>300$ 
Tabel 5. Skor Total Fungsi Ekologis Penyangga Tanah dan Pengatur Tata Air berdasarkan Vegetasi

\begin{tabular}{|c|c|c|c|c|}
\hline Kategori & Jumlah Jenis & Jumlah Individu & \% Terhadap Total Jenis & \% Terhadap Total Individu \\
\hline SB & 5 & 64 & 38 & 25 \\
\hline BK & 8 & 187 & 62 & 75 \\
\hline S & - & - & - & - \\
\hline B & - & - & - & - \\
\hline \multicolumn{5}{|c|}{ Skor total fungsi } \\
\hline
\end{tabular}

Sumber : Hasil Observasi, 2021

Skor Taman $=(\%$ terhadap total individu kategori Buruk x 1$)+(\%$ terhadap total individu kategori Sedang x 2$)+(\%$ terhadap total individu kategori Baik x 3$)+(\%$ terhadap total individu kategori Sangat baik x 4).

Keterangan Kategori Fungsi :

1. Buruk : $<200$

2. Sedang : 201-252

3. Baik : > 252

Berdasarkan hasil analisis, dari ke lima (5) fungsi ekologis, tiga (3) diantaranya berkategori baik dan dua (2) diantaranya berkategori sedang. Ada pun fungsi dengan kategori baik diantaranya yaitu fungsi modifikasi suhu, penahan angin, dan penyangga tanah dan pengatur tata air. Sementara untuk fungsi dengan kategori sedang yaitu fungsi peredam kebisingan dan fungsi pengontrol kelembapan udara. Secara keseluruhan, fungsi ekologis vegetasi pada taman ini dapat dikatakan baik, hal ini dikarenakan perawatannya intensif dilakukan.

\section{Analisis Penilaian Kondisi Lingkungan di Sekitar Taman Lansia}

Dalam analisis ini dilakukan pengukuran di sekitar wilayah taman untuk mengetahui sejauh mana efektifitas taman kota dalam mereduksi kebisingan, suhu dan kelembapan udara, kecepatan anding serta untuk mengetahui daya serap infiltrasi pada taman. Kemudian hasil tersebut dibandingkan dengan hasil penilaian fungsi ekologis berdasarkan vegetasi juga dibandingkan dengan kondisi penataan vegetasi pada taman.

Tabel 6. Hasil Pengukuran Kondisi Lingkungan Pada Taman Lansia

\begin{tabular}{|c|l|c|l|}
\hline No. & \multicolumn{1}{|c|}{ Fungsi } & $\begin{array}{c}\text { Penilaian } \\
\text { Kondisi } \\
\text { Lingkungan }\end{array}$ & \multicolumn{1}{c|}{ Keterangan } \\
\hline 1. & Peredam Kebisingan & $\mathrm{x}$ & $\begin{array}{l}\text { Hanya mampu mereduksi } \\
\text { kebisingan sebesar 6,2 dB }\end{array}$ \\
\hline 2. & Modifikasi Suhu & $\mathrm{x}$ & $\begin{array}{l}\text { Hanya mampu mereduksi suhu } \\
\text { udara sebesar } 0,5^{\circ} \mathrm{C}\end{array}$ \\
\hline 3. & Pengontrol Kelembapan Udara & $\checkmark$ & $\begin{array}{l}\text { Kelembapan udara relatif di dalam } \\
\text { taman sebesar } 61,7 \%\end{array}$ \\
\hline 4. & Penahan Angin & $\mathrm{x}$ & $\begin{array}{l}\text { Hanya mampu mengurangi } \\
\text { kecepatan angin sebesar 0,6 m/s. } \\
\text { Seharusnya mampu mengurangi } \\
\text { kecepatan angin sebesar 0,65-0,8 } \\
\text { m/s }\end{array}$ \\
\hline 5. & Penyangga Tanah dan Pengatur Tata Air & $\checkmark$ & $\begin{array}{l}\text { Kecepatan infiltrasi rata-rata } \\
\text { sebesar 4,8 s, termasuk cepat }\end{array}$ \\
\hline
\end{tabular}

Sumber : Hasil Analisis, 2021

$$
\begin{aligned}
\checkmark & : \text { Terpenuhi } \\
\mathrm{x} & : \text { Tidak Terpenuhi }
\end{aligned}
$$


Hasil pengukuran kondisi lingkungan pada Taman Lansia menunjukkan bahwa dari ke lima (5) fungsi hanya dua (2) fungsi yang memenuhi kondisi ideal yaitu fungsi pengontrol kelembapan udara dan fungsi penyangga tanah dan pengatur tata air. Belum terpenuhinya kondisi ideal dari ke tiga (3) fungsi lainnya dapat disebabkan oleh beberapa faktor seperti kondisi lalulintas di sekitar tapak taman, tingkat kebisingan di waktu pagi dan sore hari cenderung tinggi karena merupakan waktu berangkat dan pulang dari jam kerja. Selain faktor lalulintas, dapat dilihat juga dari kondisi vegetasi khususnya vegetasi pembatas antara bagian luar dan bagian dalam tapak taman sehingga dapat meningkatkatkan frekuensi kebisingan yang diukur, penataan vegetasi terutama untuk vegetasi yang menjadi pembatas antara bagian dalam dan bagian luar taman dan pada beberapa area khususnya pada area yang memiliki bagian perkerasan tidak ternaungi vegetasi.

\section{Analisis Taman Kota Sebagai Habitat Satwa}

Pada Analisis ini digunakan data jumlah spesies satwa yang ada di taman kota, kemudian dihubungkan dengan kondisi vegetasi dan juga kondisi lingkungan di sekitar taman. Taman kota dapat menyediakan aliran sungai, habitat bagi satwa liar, sarana rekreasi, dan sebagai pendaur ulang limbah secara alami. Pada Taman Lansia ditemukan sebanyak 25 jenis spesies satwa, umumnya yang banyak ditemukan adalah satwa jenis burung.
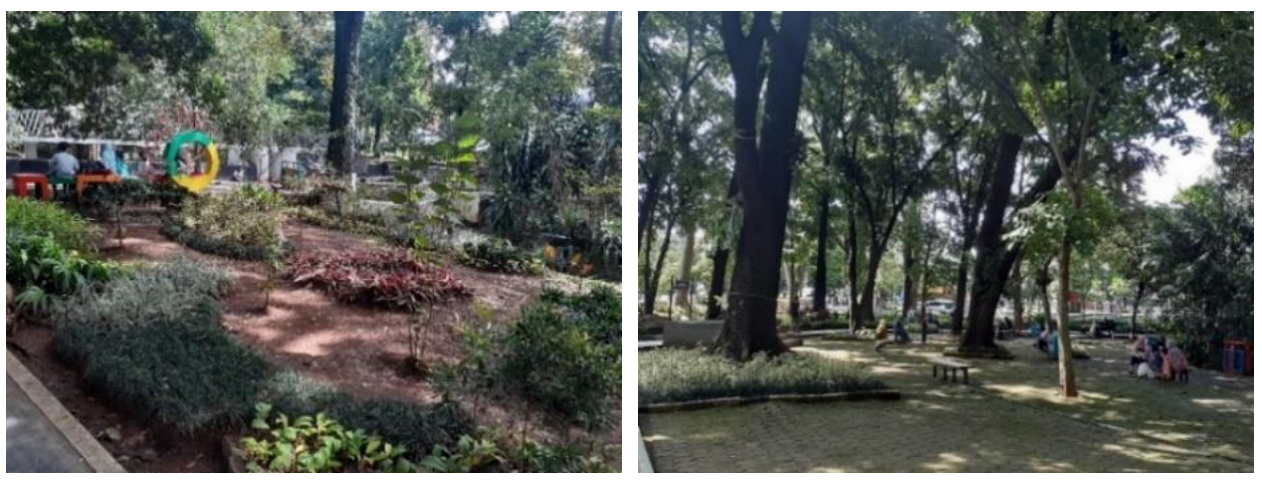

Gambar 1. Keanekaragaman Vegetasi Pada Taman Lansia

Dominasi vegetasi pada taman ini vegetasi dengan umur tua dengan ciri khas diameter batang yang besar dan tumbuh tinggi, hal ini menyebabkan adanya epifit dan lumut yang tumbuh di pohon-pohon tersebut menjadikan sumber makanan bagi satwa. Pepohonan pada taman ini umumnya memiliki daun yang lebat sehingga disukai oleh tupai hal ini dimanfaatkan oleh tupai untuk melindungi diri dari pemangsa dan menjaga mereka tetap aman saat hujan. Selain itu, pada taman ini juga terdapat beberapa pohon buah sehingga tupai menyukai tempat yang seperti ini karena buah merupakan makanan favorite bagi tupai. Intensitas aktifitas pada taman ini termasuk sepi pengunjung, tetapi hal ini justru semakin mengundang kehadiran burung karena gangguan manusia dan kebisingan dapat mempengaruhi keanekaragaman burung. Salah satu indikator penentu kesehatan taman kota adalah kehadiran burung pada area taman. Dengan demikian dapat disimpulkan bahwa keberadaan burung dengan beragam jenis spesies pada Taman Lansia menunjukan bahwa kondisi Taman Lansia dapat dikatakan sehat karena kondisi hijau pada taman ini mampu menyediakan sumber makanan dan tempat tinggal yang cukup mampu mengundang hadirnya spesies-spesies burung pada area taman. 


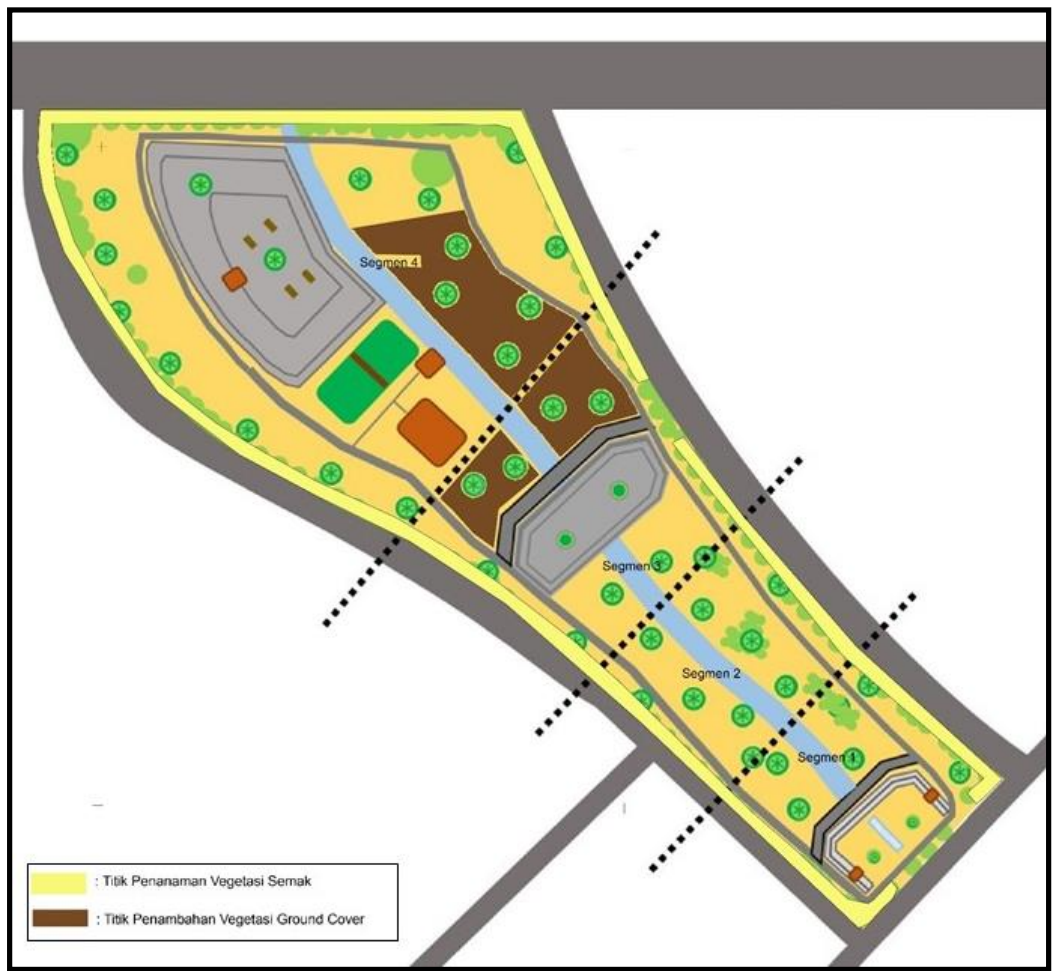

Gambar 2. Rekomendasi Area Penanaman Vegetasi Pada Taman Lansia

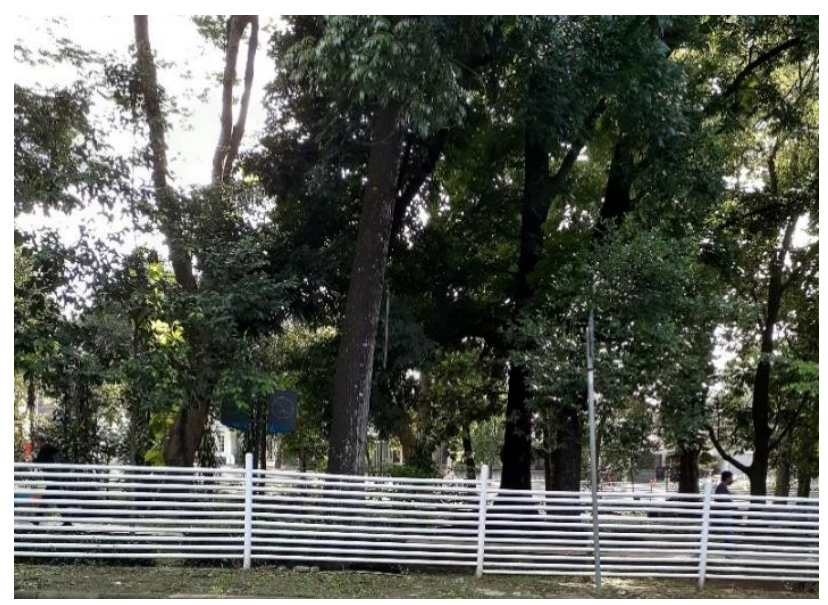

(1)

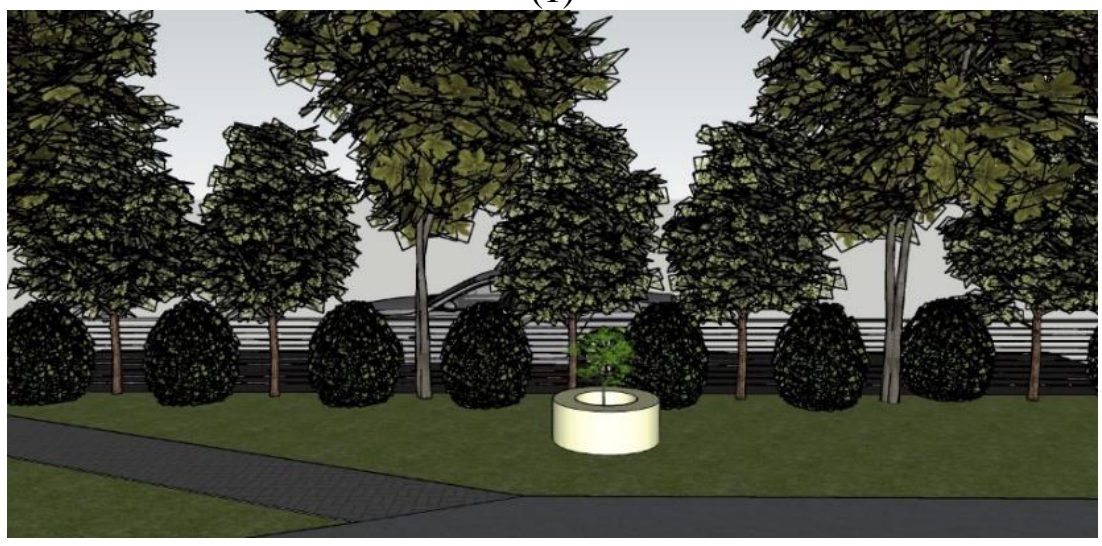

(2)

Gambar 3. (1) dan (2) Contoh Sebelum dan Sesudah Penambahan Vegetasi Semak pada Taman Lansia 

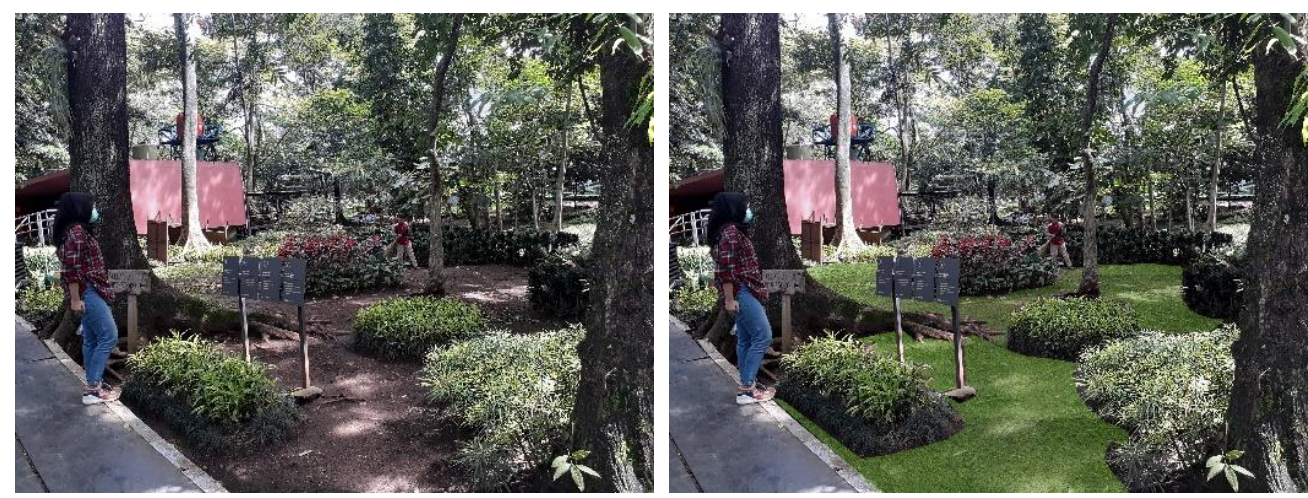

Gambar 4. Contoh Sebelum dan Sesudah Penambahan Vegetasi Ground Cover pada Taman Lansia

\section{Kesimpulan}

Berdasarkan hasil analisis yang telah dilakukan, maka peneliti menyimpulkan hal-hal sebagai berikut :

1. Kondisi vegetasi pada Taman Lansia dari ke lima (5) fungsi ekologis, tiga (3) diantaranya berkategori baik dan dua (2) diantaranya berkategori sedang. Ada pun fungsi dengan kategori baik diantaranya yaitu fungsi modifikasi suhu, penahan angin, dan penyangga tanah dan pengatur tata air. Sementara untuk fungsi dengan kategori sedang yaitu fungsi peredam kebisingan dan fungsi pengontrol kelembapan udara.

2. Hasil pengukuran kondisi lingkungan pada Taman Lansia menunjukkan bahwa dari ke lima (5) fungsi hanya dua (2) fungsi yang memenuhi kondisi ideal yaitu fungsi pengontrol kelembapan udara dan fungsi penyangga tanah dan pengatur tata air.

3. Pada Taman Lansia ditemukan sebanyak 25 spesies satwa, hal ini dikarenakan, luas taman yang relatif luas, kelengkapan jenis vegetasi pada taman ini beragam sehingga dapat menarik lebih banyak spesies burung dengan dihabitat yang berbeda.

4. Untuk meningkatkan fungsi-fungsi ekologis dapat dilakukan dengan cara dilakukannya perawatan dan pengelolaan taman secara intensif. Misalnya untuk dapat meningkatkan fungsi peredam kebisingan sehingga kebisingan tersebut dapat direduksi lebih yaitu dengan cara mengganti pohon yang sudah rusak dan menambah vegetasi dengan ketinggian yang bervariasi pada bagian tersebut. Selain itu, komposisi penanaman vegetasi dengan ketinggian berbeda akan menjadikan kerapatan vegetasi lebih padat, penanaman yang padat ini juga dapat meningkatkan perlindungan terhadap angin dan terciptanya iklim mikro, kecepatan dan kekuatan angin mampu direduksi 75-85\% [8]. Jenis vegetasi yang dapat ditambahkan dapat berupa vegetasi jenis semak, ada pun contohnya adalah Nusa Indah (Mussaenda pubescens), Kol Banda (Pisonia alba Spanoghe), atau pun Bonsai Kimeng (Ficus malacocarpa). Lalu Pada beberapa bagian di Taman Lansia masih berupa tanah dapat ditanami rumput sebagai tanaman Ground Cover, Ada pun contoh vegetasi Ground Cover yang dapat ditanami pada taman yaitu yang memiliki ciri ketinggian mulai dari 0 (nol) hingga setinggi mata kaki misalnya seperti rumput-rumputan, Lili Turf (Ophiopogon), dan Ubi Hias (Ipomoea batatas).

\section{Acknowledge}

Penulis mengucapkan terima kasih kepada keluarga khususnya kedua orang tua penulis, Ibu Verry Damayanti ST. MT. Selaku dosen pembibing yang selalu memberikan saran, masukan, serta motivasi selama penulis menyelesaikan tugas akhir ini, lalu untuk teman-teman yang selalu memberikan semangat dalam proses penyusunan tugas akhir dan juga selama masa perkuliahan. 


\section{Daftar Pustaka}

[1] Fenny Aprillia, K., Lie, T., \& Saputra, C. (2020). Karakteristik desain ruang terbuka hijau pada sempadan sungai perkotaan. ARTEKS : Jurnal Teknik Arsitektur, 5(2), 235-244. https://doi.org/10.30822/arteks.v5i2.394

[2] Fuady, M. (2011). Ruang terbuka hijau ekologis sebagai penyedia oksigen dan penyimpan air untuk kota banda aceh. 2008.

[3] Imansari, N., \& Khadiyanta, P. (2015). Penyediaan Hutan Kota dan Taman Kota sebagai Ruang Terbuka Hijau (RTH) Publik Menurut Preferensi Masyarakat di Kawasan Pusat Kota Tangerang. Ruang, 1(3), 101-110. https://doi.org/10.14710/ruang.1.3.101-110

[4] Samsudi. (2010). Ruang Terbuka Hijau Kebutuhan Tata Ruang Perkotaan Kota Surakarta. In Journal of Rural and Development: Vol. Vol. 1 (Issue No. 1).

[5] Weishaguna, W., Ekasari, A. M., Damayanti, V., \& Rochman, G. P. (2020). The Concept of Biodiversity Park Plan and Design for Abandoned Land Based on Community Participation. 409(SoRes 2019), 312-315. https://doi.org/10.2991/assehr.k.200225.065

[6] Yang, X., Tan, X., Chen, C., \& Wang, Y. (2020). The influence of urban park characteristics on bird diversity in Nanjing, China. Avian Research, 11(1), 1-9. https://doi.org/10.1186/s40657-020-00234-5

[7] Chaiyarat, R., Wutthithai, O., Punwong, P., \& Taksintam, W. (2019). Relationships between urban parks and bird diversity in the Bangkok metropolitan area, Thailand. Urban Ecosystems, 22(1), 201-212. https://doi.org/10.1007/s11252-018-0807-1

[8] MAHARDI, F. (2019). Evaluasi Fungsi Ekologis Dan Estetika Pada Beberapa Taman Kota Di Jakarta. https://doi.org/10.31237/osf.io/y4pgs

[9] Damayanti, V. (2019). Potensi Pengembangan Infrastruktur Hijau dalam Upaya Mewujudkan Cimahi sebagai Kota Hijau Berkelanjutan. ETHOS (Jurnal Penelitian Dan Pengabdian), 7(2), 233-243. https://doi.org/10.29313/ethos.v7i2.4560 